\title{
Genetic diversity and phylogenetic relationship among Anabantoidei fish (Anabantiformes) in South Kalimantan, Indonesia based on SDS-PAGE analysis
}

\author{
RANI SASMITA ${ }^{\natural}$, MABRUR ${ }^{\text {v }}$, UMMY SHALIHA AULIA RAHMY, BADRUZSAUFARI ${ }^{\text {}}$ \\ Department of Biology, Faculty of Mathematics and Natural Sciences, Universitas Lambung Mangkurat. Jl. A. Yani KM.36, Banjarbaru 70714, South

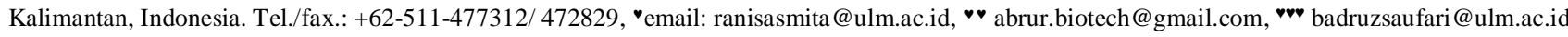

Manuscript received: 1 July 2019. Revision accepted: 15 August 2019.

\begin{abstract}
Sasmita R, Mabrur, Rahmy USA, Badruzsaufari. 2019. Genetic diversity and phylogenetic relationship among Anabantoidei fish (Anabantiformes) in South Kalimantan, Indonesia based on SDS-PAGE analysis. Biodiversitas 20: 2519-2527. Protein profile is a molecular marker for diversity and phylogenetic analysis of germplasm, including Anabantoidei fish which is abundant in freshwater ecosystem of South Kalimantan. The aim of this research was to analyze genetic diversity and construct phylogenetic relationship among Anabantoidei fish based on SDS PAGE analysis. Protein was extracted from muscle tissue of six species of Anabantoidei fish and precipitated using Ammonium sulfate salt. Soluble protein content was determined using Bradford assay and then separated based on SDS-PAGE method. Genetic diversity and phylogenetic relationship were constructed using PAST software based on UPGMA method. The results showed that the soluble protein of fish muscle can be precipitated optimally in different ammonium sulfate concentration. Based on SDS-PAGE analysis, 59 different protein bands have been separated from gels with molecular weight ranging from 28.15 to $181.61 \mathrm{kDa}$. On the protein level, the Anabantoidei fish showed high genetic polymorphism (greater than 90\%) with 3, 2 and 5 monomorphic bands on non-precipitated, AS-precipitated and combination between non- and AS-precipitated proteins, respectively. The phylogenetic reconstruction also exhibited that the Anabantoidei fish has the unique phylogenetic trees, especially for the combined protein datasets. This information would be useful for freshwater fish conservation and breeding programs.
\end{abstract}

Keywords: Anabantoidei, Bradford, diversity, protein profile, SDS-PAGE

\section{INTRODUCTION}

Indonesia has the highest diversity of freshwater fish in Asia and became the second country with highest freshwater fish diversity in the world (Kottelat and Whitten 1996). According to Fishbase (2019), approximately 1.236 freshwater fish species are found in Indonesia as the endemic, native, introduced or reintroduced species. In South Kalimantan, suborder Anabantoidei is very abundant in the freshwater ecosystem. These fish have been consumed freshly, salted dry or as fermented food like "pakasam and wadi" by local people. The suborder consisted of three families, which is Anabantidae, Helostomatidae, and Osphronemidae (Ruber 2009). According to Nelson (2016), 120 fish species which grouped into 19 genera belong to these group. However, only ten genera are reported in Indonesia including Anabas, Helostoma, Belontia, Betta, Luciocephalus, Osphronemus, Parosphronemus, Sphaerichthys, Trichogaster and Trichopsis (Fishbase 2019).

Anabantoidei fish are uniquely adapted to freshwater ecosystem with low dissolved oxygen (Maidie et al. 2015). This ability is caused by gill modification and forming an accessory structure which known as labyrinth. This accessory has a function to exchange gases directly from aerial environment. Labyrinth organ is a suprabranchial organ containing complex folding that covered with respiratory epithelium and increases respiratory surface (Ruber 2009). Based on this ability, Anabantoidei also known or popular as labyrinth or air-breathing fish (Bone and Moore 2007). According to Betancur-R et al. (2017), Labyrinth has existed in the other suborder, i.e. Channoidei. The suborder was consisted of one family, Channidae, whereas 12 species have been reported in Indonesia (Fishbase 2019). Along with suborder Nandoidei, the suborder of Channoidei and Anabantoidei has been classified as a new order i.e. Anabantiformes (Betancur-R et al. 2017).

Some human activities have affected the freshwater ecosystem as habitat for Anabantoidei fish. According to Quyen et al. (2015), freshwater fish biodiversity is under pressure due to the overexploitation, dam building, and environmental pollution. Urbanization, industrialization, agriculture (pesticide and chemical fertilizer) and mining are contributed to the environmental pollution in the freshwater ecosystem (Zhuo and Guo 2015). Thus, the conservation program is needed for freshwater fish including, suborder Anabantoidei. According to Karp et al. (1997), understanding and studying the character of germplasm including genetic diversity are very important as supporting activity of biodiversity conservation.

Protein profile is one of molecular markers for genetic diversity and phylogenetic analysis of germplasm (Porto et al. 2001). This information obtained by protein separation based on their molecular weight using SDS-PAGE technique (Roy and Kumar 2012). Protein profiles have been used as markers for genetic diversity assessment of 
the freshwater fish, including snapper fish (Lutjanidae) (Velamala et al. 2017), snakehead (Channidae) (Haniffa et al. 2017), Oreochromis niloticus (Elghobashy et al. 2005), Carp (Saxena and Soranganba 2014), Lethrinus borbonicus, Siganus rivulatus and Mulloidichthys flavolineatus (Ebied et al. 2014), and Labeo rohita and Cirrhinus mrigala (Mahboob et al. 2012). Therefore, this study proposed to access genetic diversity of Anabantoidei fish collected from South Kalimantan based on protein profiles obtained from SDS-PAGE analysis.

\section{MATERIALS AND METHODS}

\section{Study area}

Fish samples were collected from freshwater ecosystem of three different sampling sites in South Kalimantan, Indonesia: District of Banjar, Barito Kuala and Hulu Sungai Tengah (Figure 1, Table 1). The fish were collected based on purposive sampling method and then transported in to the Laboratory of Universitas Lambung Mangkurat. The body weight and length of the fish were measured and then the muscle was separated from the bone, digestive tract, gills, and other organs. Fish muscle was stored at the temperature $-20^{\circ} \mathrm{C}$ for protein profiles analysis.

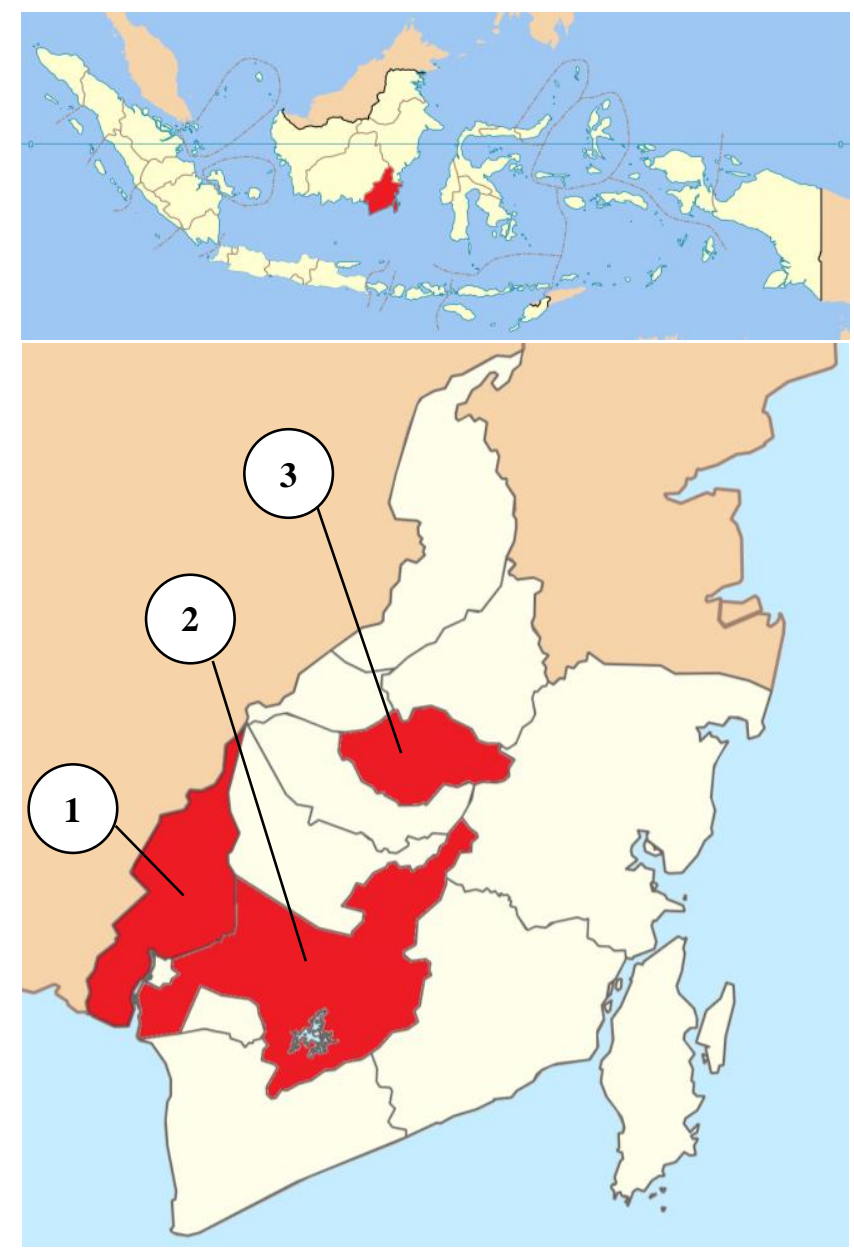

Figure 1. Location of sample collection in South Kalimantan, Indonesia: 1. District of Barito Kuala, 2. District of Banjar, 3. District of Hulu Sungai Tengah.

\section{Protein extraction}

Fish muscle was homogenized with Tris EDTA buffer (0.5 M Tris on pH 8.3 and $1 \mathrm{mM}$ EDTA) with tissue-buffer ratio $1: 3(\mathrm{w} / \mathrm{v})$ and then centrifuged at $10.000 \mathrm{~g}$ for 10 minutes at $4^{\circ} \mathrm{C}$. The supernatants were collected and stored at the temperature $-20^{\circ} \mathrm{C}$ (Dekic et al. 2016).

\section{Protein precipitation using ammonium sulfate}

Protein supernatant has been precipitated based on Burgess (2009) using different Ammonium sulfate (AS) saturation (from $20 \%$ to $80 \%$ ) at the temperature $0^{\circ} \mathrm{C}$. Ammonium sulfate was added as initial saturation (20, 30, 40, 50, 60 and 70\%) and then incubated for 30 minutes at $0^{\circ} \mathrm{C}$. Protein-AS solution was centrifuged at $15.000 \mathrm{~g}$ for 15 minutes at $4^{\circ} \mathrm{C}$. After that, AS was added again to raise the saturation into $30,40,50,60,70$, and $80 \%$ from initial saturation. Protein-AS solution then incubated for 30 minutes at $0^{\circ} \mathrm{C}$ and centrifuged at $15.000 \mathrm{~g}$ for 15 minutes at $4^{\circ} \mathrm{C}$. After discarding the supernatant, the collected pellet was resuspended with Tris $\mathrm{HCl} 10 \mathrm{mM} \mathrm{pH} \mathrm{8,0.} \mathrm{The} \mathrm{protein}$ extract was stored on $-20^{\circ} \mathrm{C}$ for further analysis.

\section{Bradford assay}

Protein concentration was analyzed based on Bradford Assay (1976) using Bradford reagent (Amresco, USA) according to the manual. The absorbance of protein was measured at $595 \mathrm{~nm}$ using Spectrostar Nano Spectrophotometer (BMG Labtech). Protein concentration was determined based on linear regression between absorbance (OD) and concentration of Bovine Serum Albumin (HiMedia) as standard protein.

\section{Electrophoresis and staining}

SDS-PAGE was performed according to Laemmli (1970) with modification by Hidayaturrahmah et al. (2019). Protein bands were separated on $1 \mathrm{~mm}$ thick slab containing $10 \%$ polyacrylamide of separating gel and 5\% on stacking gel using Maxi Vertical Gel Electrophoresis Apparatus - MV 20 DSYS (Major Science). Protein was separated from non-precipitated and AS-precipitated extract. The protein was separated on 120 voltage, $40 \mathrm{~mA}$ for 3 hours. Protein ladder that used in this research is Chromatein Prestained Protein Ladder (Vivantis). Gel was stained in staining solution containing Coomassie Brilliant Blue R-250 (HiMedia).

\section{Data analysis}

Molecular weights of separated bands were determined based on linear regression fit between Relative mobility value ( $\mathrm{Rf}$ ) and log molecular weights of protein ladder. Rf was measured based on the equation according to Haniffa et. al. (2017):

$$
\mathrm{Rf}=\frac{\text { protein migration distance }(\mathrm{cm})}{\text { tracking dye distance }(\mathrm{cm})}
$$

The variations of SDS-PAGE results were scored based on presence (1) and absence (0) of protein bands on the image taken from the gels. This binary data was converted in to Dice similarity coefficient based on Nei and $\mathrm{Li}$ (1979): 


$$
\mathrm{F}_{\mathrm{ab}}=\frac{2 \mathrm{n}_{\mathrm{ab}}}{\left(\mathrm{n}_{\mathrm{a}}+\mathrm{n}_{\mathrm{b}}\right)}
$$

The $\mathrm{F}_{\mathrm{ab}}$ represent the genetic similarity between $a$ and $b, \mathrm{n}_{\mathrm{ab}}$ represent the number of same bands of $a$ and $b$, and $\mathrm{n}_{\mathrm{a}}$ and $\mathrm{n}_{\mathrm{b}}$ represent the number of bands of $a$ and $b$, respectively. (Thada and Jaglan 2013). The phylogenetic trees were constructed based on UPGMA method using PAST (Paleontological Statistic Software) $3^{\text {rd }}$ version (Hammer et al. 2001). Topological robustness was assessed by bootstrap analysis with 1000 replicates (Fenselstein, 1985).

\section{RESULTS AND DISCUSSION}

\section{Sample collection and identification}

Six fish species were collected from three different study areas of South Kalimantan: Trichogaster trichopterus, Trichogaster pectoralis, Helostoma temminckii, Anabas testudineus, Belontia hasselti and Osphronemus goramy (Table 1, Figure 2). These fish previously reported from Barito river, Danau Panggang (District of Hulu Sungai Utara), Danau Bangkau (District of Hulu Sungai Selatan) and Danau Talan (District of Balangan). Other Anabantoidei fish also reported in South Kalimantan, Trichogaster leerii and Betta anabatoides (Prasetyo and Asyari 2003; Prasetyo 2006a; Yunita 2012). According to the Fishbase data (2019), four species of Trichogaster (T. trichopterus, T. pectoralis, T. leerii and T. poptae), three species Ospronemus ( $O$. goramy, $O$. laticlavius and $O$. septemfasciatus) and one species of Anabas, Helostoma and Belontia are found in Indonesia. Beside for consumption, some genera of Anabantoidei fish has great potential as ornamental fish i.e. Betta (Yunita 2012); Anabas (Maidie et al. 2015); Trichogaster (Subharanjani et al. 2015); and Belontia (Haryono 2012).

\section{Effect of Ammonium sulfate precipitation on fish protein}

The protein was extracted from the fish muscle using Tris EDTA buffer and then the concentration was measured based on Bradford assay. The concentration of protein extract is shown in Table 2. The result showed that the concentration of protein extract was affected by ammonium sulfate addition in the different saturation. Optimum ammonium sulfate saturation was different between fish species: $40-50 \%$ for $B$. hasselti, $50-60 \%$ for $H$. temminckii and $O$. goramy; $70-80 \%$ for T. trichopterus, T. pectoralis, and A. testudineus. These result depending by the hydrophobic amino acids residues of fish proteins. The protein with high hydrophobic residues would be precipitated on Ammonium sulfate solution, however, hydrophilic proteins would be eliminated at this stage.

According to Wingfield (2001), solubility of protein was increased due to the effect of salt addition and usually decreases at the higher salt concentration. Hydrophobic interaction between protein and water are increased by ammonium sulfate addition and then protein was folded. Meanwhile, only hydrophobic protein can be precipitated and crystal formed when ammonium sulfate was added. Thus, the hydrophilic protein can not precipitate with ammonium sulfate or other salts. This result has been demonstrated in this study, whereas the number of precipitated protein band was less when compared with the not-precipitated protein. Ammonium sulfate precipitation also affected by crystal conformation of proteins (Dumetz et al. 2007). Concentration of protein extract depends on the $\mathrm{pH}$, hydrophobicity, ion capacity, protein size, type of salt and extraction method (Zhang 2012). In addition, the optimum ammonium sulfate concentration for fish protein precipitation is different between fish species or geographical origin (Hidayaturrahmah et al. 2019).

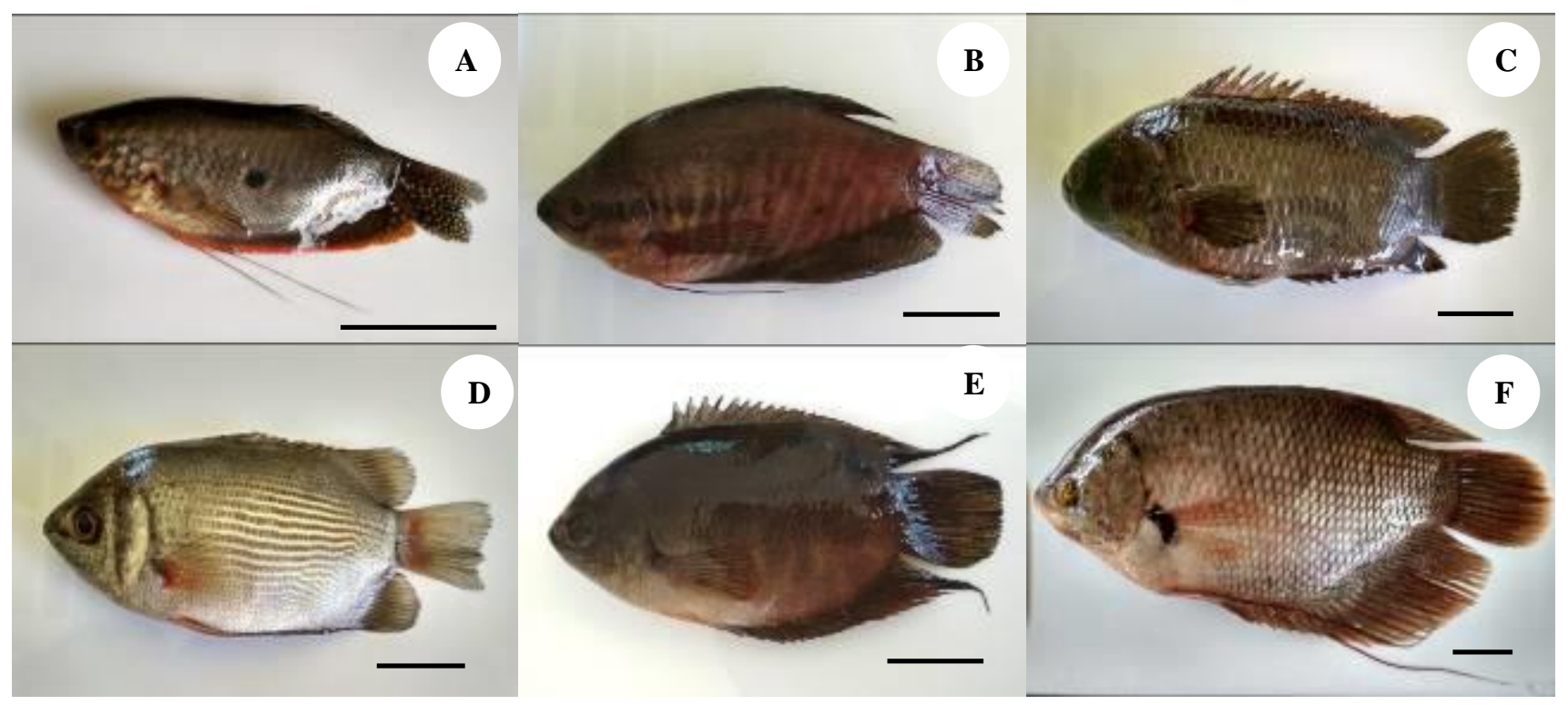

Figure 2. Anabantoidei fish collected from the freshwater ecosystem of South Kalimantan. A. Trichogaster trichopterus, B. Trichogaster pectoralis, C. Anabas testudineus, D. Helostoma temminckii, E. Belontia hasselti, F. Osphronemus goramy. Scale bar $=3 \mathrm{~cm}$. 
Table 1. Anabantoidei fish in the present study

\begin{tabular}{|c|c|c|c|c|c|}
\hline Fish & Local name & Family & $\begin{array}{l}\text { Sampling } \\
\text { location } \\
\text { (District) }\end{array}$ & $\begin{array}{l}\text { Previously reported } \\
\text { (based on the reference) }\end{array}$ & $\begin{array}{l}\text { The way for } \\
\text { consumption by local } \\
\text { people }\end{array}$ \\
\hline Trichogaster trichopterus & Sepat Rawa & Osphronemidae & Banjar & Barito river basin ${ }^{1}$, Danau Bangkau ${ }^{4}$ & $\begin{array}{l}\text { Fresh consumed, } \\
\text { fermented "Pakasam" } \\
\text { and salted dry fish }\end{array}$ \\
\hline Trichogaster pectoralis & Sepat Siam & Osphronemidae & $\begin{array}{l}\text { Hulu Sungai } \\
\text { Tengah }\end{array}$ & $\begin{array}{l}\text { Barito river basin }{ }^{1}, \text { Danau Talan }{ }^{2}, \\
\text { Danau Panggang }^{3}, \text { Danau Bangkau }^{4}\end{array}$ & $\begin{array}{l}\text { Fresh consumed, } \\
\text { fermented "Wadi" and } \\
\text { salted dry fish }\end{array}$ \\
\hline Helostoma temminckii & Biawan & Helostomatidae & Banjar & $\begin{array}{l}\text { Barito river basin }{ }^{1}, \text { Danau Talan }{ }^{2}, \\
\text { Danau Panggang }^{3}, \text { Danau Bangkau }^{4}\end{array}$ & $\begin{array}{l}\text { Fresh consumed and } \\
\text { salted dry fish }\end{array}$ \\
\hline Anabas testudineus & Papuyu & Anabantidae & Banjar & $\begin{array}{l}\text { Barito river basin }{ }^{1}, \text { Danau Talan }{ }^{2}, \\
\text { Danau Panggang }^{3}, \text { Danau Bangkau }^{4}\end{array}$ & $\begin{array}{l}\text { Fresh consumed, } \\
\text { fermented "Wadi" and } \\
\text { salted dry fish }\end{array}$ \\
\hline Belontia hasselti & Kapar & Osphronemidae & Barito Kuala & Barito river basin ${ }^{1}$, Danau Bangkau ${ }^{4}$ & Fresh consumed \\
\hline Osphronemus goramy* & $\begin{array}{l}\text { Gurame } \\
\text { (Kalui) }\end{array}$ & Osphronemidae & Banjar & Barito river basin ${ }^{1}$, Danau Bangkau ${ }^{4}$ & Fresh consumed \\
\hline
\end{tabular}
Notes: *cultured fish. References: ${ }^{1}$ Prasetyo and Asyari (2003) and Prasetyo (2006a); ${ }^{2}$ Burnawi (2009); ${ }^{3}$ Prasetyo (2006b); ${ }^{4}$ Yunita (2012)

Table 2. The concentration of protein extract that precipitated on different Ammonium sulfate saturation (\%)

\begin{tabular}{lccccccc}
\hline \multirow{2}{*}{ Fish sample } & \multicolumn{7}{c}{ Concentration of protein extract $\left(\mathbf{m g . m l} \mathbf{-}^{-\mathbf{1}}\right.$} \\
\cline { 2 - 8 } & $\mathbf{0}$ & $\mathbf{2 0 - 3 0}$ & $\mathbf{3 0 - 4 0}$ & $\mathbf{4 0 - 5 0}$ & $\mathbf{5 0 - 6 0}$ & $\mathbf{6 0 - 7 0}$ & $\mathbf{7 0 - 8 0}$ \\
\hline Trichogaster trichopterus & $3.952 \pm 0.105^{\mathrm{b}}$ & $3.498 \pm 0.138^{\mathrm{a}}$ & $3.678 \pm 0.160^{\mathrm{ab}}$ & $3.715 \pm 0.092^{\mathrm{ab}}$ & $5.087 \pm 0.030^{\mathrm{c}}$ & $4.883 \pm 0.068^{\mathrm{c}}$ & $5.598 \pm 0.779^{\mathrm{d}}$ \\
Trichogaster pectoralis & $4.063 \pm 0.343^{\mathrm{ab}}$ & $3.677 \pm 0.173^{\mathrm{a}}$ & $6.103 \pm 0.363^{\mathrm{c}}$ & $5.502 \pm 0.141^{\mathrm{cd}}$ & $5.634 \pm 0.868^{\mathrm{c}}$ & $4.647 \pm 0.381^{\mathrm{b}}$ & $6.662 \pm 0.138^{\mathrm{d}}$ \\
Anabas testudineus & $4.232 \pm 0.118^{\mathrm{b}}$ & $4.025 \pm 0.128^{\mathrm{a}}$ & $3.919 \pm 0.152^{\mathrm{a}}$ & $5.372 \pm 0.087^{\mathrm{c}}$ & $5.228 \pm 0.147 \mathrm{c}$ & $5.163 \pm 0.108^{\mathrm{c}}$ & $5.314 \pm 0.050^{\mathrm{c}}$ \\
Helostoma temmincki $^{\mathrm{a}}$ & $4.560 \pm 0.146^{\mathrm{ab}}$ & $4.694 \pm 0.093^{\mathrm{b}}$ & $4.376 \pm 0.088^{\mathrm{a}}$ & $4.598 \pm 0.151^{\mathrm{ab}}$ & $5.230 \pm 0.203^{\mathrm{c}}$ & $4.605 \pm 0.040^{\mathrm{ab}}$ & $4.631 \pm 0.027^{\mathrm{b}}$ \\
Belontia hasselti & $4.506 \pm 0.384^{\mathrm{c}}$ & $3.749 \pm 0.065^{\mathrm{ab}}$ & $3.860 \pm 0.072^{\mathrm{b}}$ & $3.376 \pm 0.433^{\mathrm{a}}$ & $4.738 \pm 0.017^{\mathrm{cd}}$ & $4.846 \pm 0.312^{\mathrm{cd}}$ & $5.130 \pm 0.021^{\mathrm{d}}$ \\
Osphronemus goramy & $4.544 \pm 1.003^{\mathrm{b}}$ & $3.510 \pm 0.214^{\mathrm{a}}$ & $3.355 \pm 0.111^{\mathrm{a}}$ & $4.612 \pm 0.148^{\mathrm{b}}$ & $4.957 \pm 0.109^{\mathrm{b}}$ & $4.494 \pm 0.105^{\mathrm{b}}$ & $4.888 \pm 0.102^{\mathrm{b}}$ \\
\hline Not Valus
\end{tabular}

Note: Values represent the mean of three replicates \pm standart deviation. The same letters indicate no significant difference between columns in the row by Duncan test at the $5 \%$ level

\section{Protein Profiles of Anabantoidei fish}

Protein profiles of Anabantoidei fish obtained by two different protein extracts from non-precipitated and ASprecipitated (Figure 3). The non-precipitated and ASprecipitated protein extracts were performed in different $10 \%$ resolving gel. The result of linear regression analysis between the Rf and $\log$ molecular weight of protein ladder showed standard curve graph with the equation $\mathrm{y}=$ $0.9331 \mathrm{x}+2.43496$ and $\mathrm{y}=-0.9923 \mathrm{x}+2.386$ for nonprecipitated and AS-precipitated gels, respectively. The value of $R^{2}=0.9879$ and 0.9873 indicated that the standard curve of protein ladder expressed has high accuracy (Hidayati et al. 2016). The molecular weight of protein profiles was measured based on the equation from the standard curve of protein ladder. The result showed that the molecular weight of Anabantoidei fish muscle protein ranged from 28.15 to $181.61 \mathrm{kDa}$ (Figure 3).

Approximately 59 protein bands were separated from non-precipitated and AS-precipitated muscle protein extract of Anabantoidei fish on 10\% resolving gels. Our previous study successfully separated protein with molecular weight ranging $24-191 \mathrm{kDa}$ from snakehead (Channa striata) (Mabrur et al. 2018), 24 - $146 \mathrm{kDa}$ from Pangasius hypophthalmus protein and $25-135 \mathrm{kDa}$ from Hemibagrus nemurus on 10\% resolving gels (Sasmita et al.
2018). Polyacrylamide gel with $10 \%$ resolving gel is the best concentration for protein separation with molecular weight ranging from 14 to $200 \mathrm{kDa}$ (Rath et al. 2013). The results of SDS-PAGE analysis of protein has demonstrated that it is different in the number of bands and molecular weight between non-precipitated and AS-precipitated. These results can be affected by Ammonium sulfate precipitation process. In our study, $15 \mu \mathrm{g}$ protein was loaded into polyacrylamide gel wells. According to Hidayaturrahmah et al. (2019), $15 \mu \mathrm{g}$ protein per wells gives great screening result with the maximum number of band.

Fish muscle was composed of sarcoplasmic, myofibrillar and stromal proteins which differ in functions and solubility (Sasmita et al. 2018). These proteins have different functions as structural and functional proteins i.e. enzymes. The molecular weight of the same proteins also differs between fish species or in same species from different origins. The differences of proteins not only was showed in the molecular weight, but also in protein structure and amino acids sequence. According to Gam et al. (2006), muscle protein of fish has functioned as the structural (cell component), ribosomal, functional (enzymes), transport, transcription and translation factor, calcium ion binding, DNA- and RNA-binding proteins. 


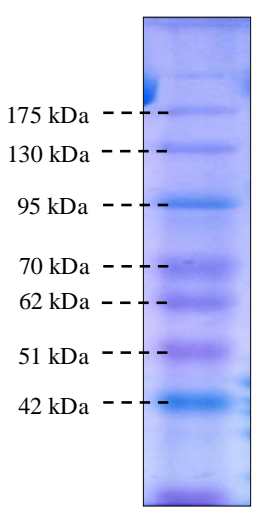

M

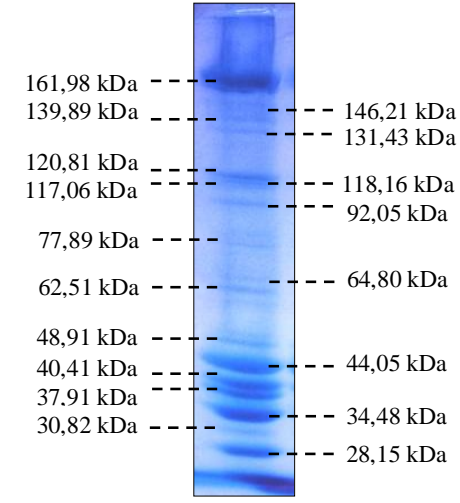

A1

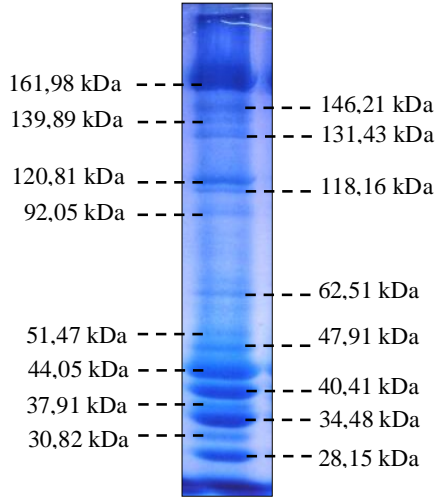

B1

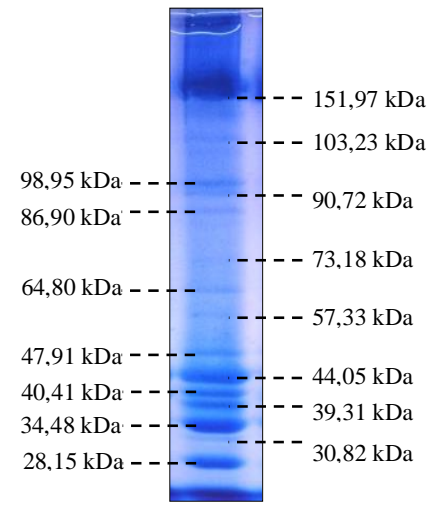

C1

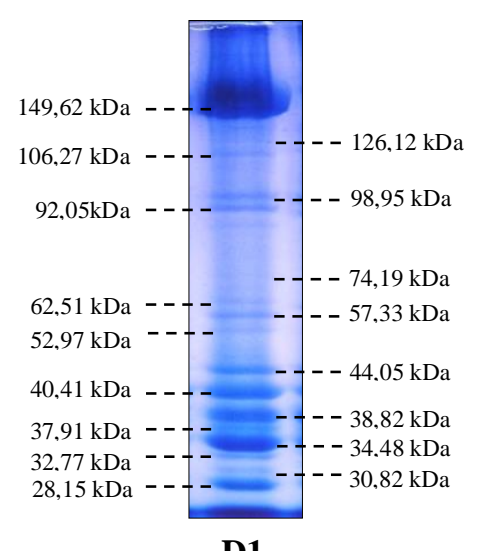

D1

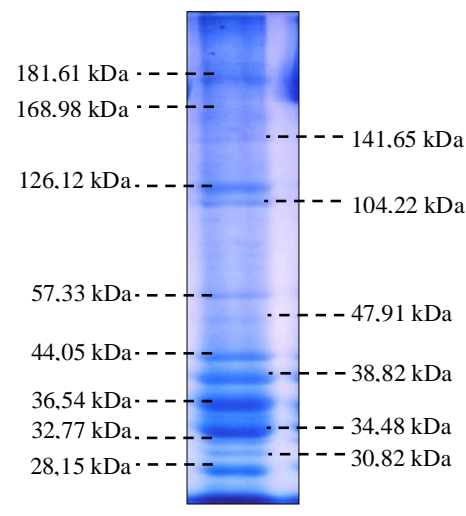

E1

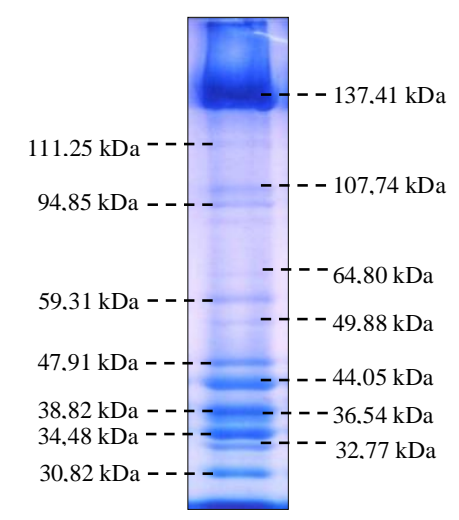

F1

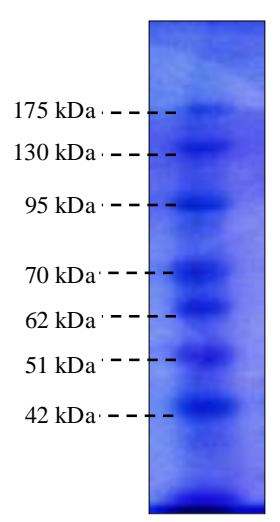

$\mathbf{M}$

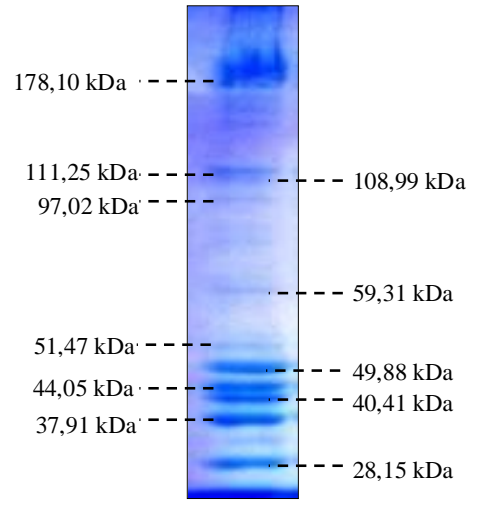

A2

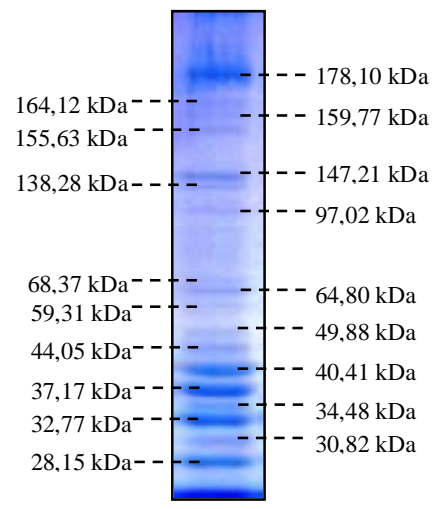

B2

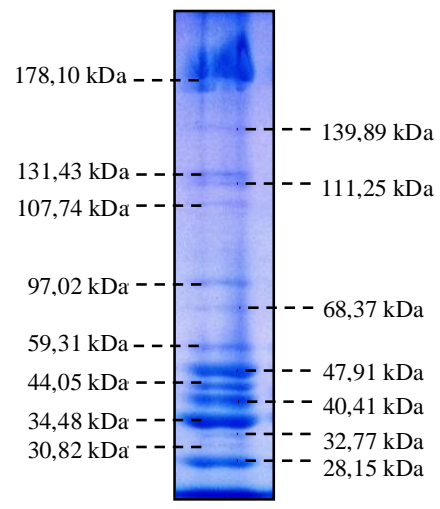

C2

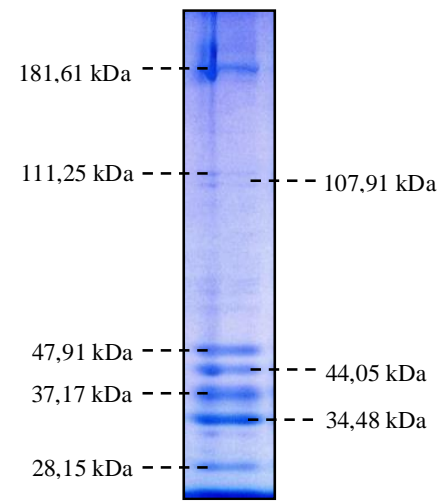

D2

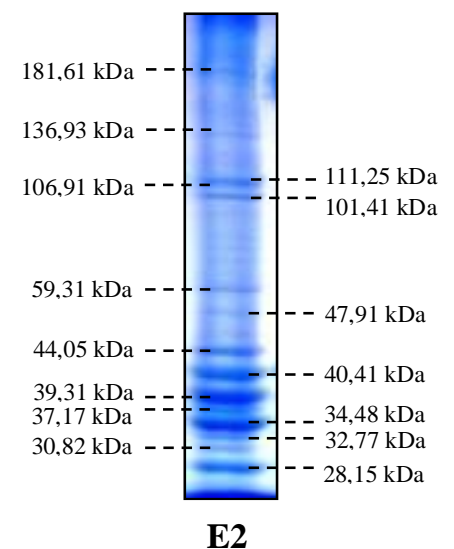

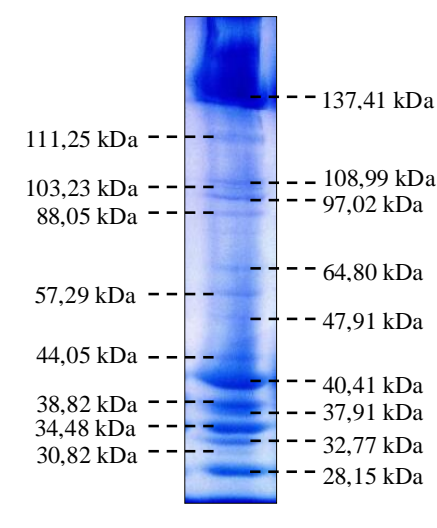

F2

Figure 3. Protein profiles of Anabantoidei fish. (M) Protein ladder, Chromaterin Prestained Protein Ladder [Vivantis]. A. Trichogaster trichopterus, B. Trichogaster pectoralis, C. Anabas testudineus, D. Helostoma temminckii, E. Belontia hasselti, F. Osphronemus goramy. The number (1) represent protein profiles of non-precipitated and (2) represent protein profiles of AS-precipitated fish protein extract 
Table 3.A. Genetic similarity coefficient between Anabantoidei fish based on non-precipitated protein bands data

\begin{tabular}{ccccccc}
\hline OTUs & A & B & C & D & E & F \\
\hline A & 1.000 & & & & & \\
B & 0.882 & 1.000 & & & & \\
C & 0.424 & 0.387 & 1.000 & & & \\
D & 0.457 & 0.485 & 0.438 & 1.000 & & \\
E & 0.313 & 0.333 & 0.414 & 0.516 & 1.000 & \\
F & 0.313 & 0.267 & 0.345 & 0.323 & 0.500 & 1.000 \\
\hline
\end{tabular}

Table 3.B. Genetic similarity coefficient between Anabantoidei fish based on AS-precipitated protein bands data

\begin{tabular}{ccccccc}
\hline OTUs & A & B & C & D & E & F \\
\hline A & 1.000 & & & & & \\
B & 0.500 & 1.000 & & & & \\
C & 0.583 & 0.533 & 1.000 & & & \\
D & 0.400 & 0.385 & 0.455 & 1.000 & & \\
E & 0.308 & 0.375 & 0.429 & 0.667 & 1.000 & \\
F & 0.444 & 0.364 & 0.414 & 0.400 & 0.452 & 1.000 \\
\hline
\end{tabular}

Table 3.C. Genetic similarity coefficient between Anabantoidei fish based on combined (non- and AS-precipitated) protein bands data

\begin{tabular}{ccccccc}
\hline OTUs & A & B & C & D & E & F \\
\hline A & 1.000 & & & & & \\
B & 0.808 & 1.000 & & & & \\
C & 0.531 & 0.510 & 1.000 & & & \\
D & 0.426 & 0.408 & 0.435 & 1.000 & & \\
E & 0.298 & 0.286 & 0.478 & 0.591 & 1.000 & \\
F & 0.522 & 0.417 & 0.533 & 0.419 & 0.465 & 1.000 \\
\hline
\end{tabular}

Note: OTUs (Operational Taxonomic Units). A. Trichogaster trichopterus, B. Trichogaster pectoralis, C. Belontia hasselti, D. Helostoma temminckii, E. Anabas testudineus, F. Osphronemus goramy

\section{Genetic diversity and phylogenetic relationship among Anabantoidei fish}

Protein of Anabantoidei fish in South Kalimantan, Indonesia showed high genetic polymorphism (greater than $90 \%$ ) which were $93.47 \%, 94.59 \%$ and $91.52 \%$ for nonprecipitated, AS-precipitated and combined datasets, respectively. Three monomorphic bands have been observed on non-precipitated dataset with the molecular weights of $44.05,34.48$ and $30.82 \mathrm{kDa}$, two bands on ASprecipitated dataset with the molecular weights of 44.05 and $28.15 \mathrm{kDa}$, and five bands on combined dataset with the molecular weights of $47.91,44.05,34.48,30.82$ and $28.15 \mathrm{kDa}$.

The phylogenetic tree was obtained for the nonprecipitated protein profiles from Anabantoidei fish. The genetic similarity coefficient is shown in Table 3.A-3B. Based on non-precipitated protein (Figure 4.A),
Anabantoidei fish were separated into three groups with relatively low values of bootstrap support (bs). The highest genetic similarity (gs) was observed between $T$. trichopterus and $T$. pectoralis with genetic similarity coefficient 0.882 at bs $=99 \%$. On this phylogenetic tree, $A$. testudineus, B. hasselti and Helostoma temminckii has been grouped into one group. $O$. goramy, a cultured species that used in this study, has far related to $T$. pectoralis ( $\mathrm{gs}=$ 0.267 ) and T. trichopterus ( $\mathrm{gs}=0.313$ ), at $\mathrm{bs}=100 \%$.

Another phylogenetic tree was obtained for the ASprecipitated protein profiles from Anabantoidei fish shown in Figure 4.B. In general, two independent groups of these fish populations were resolved by the AS-precipitated protein. Differ from the non-precipitated, the ASprecipitated dataset was able to combine $O$. goramy with $H$. temminckii and A. testudineus, at bs $=31 \%$. Same as non-precipitated, the $H$. temminckii has closely related to $A$. testudineus with the highest genetic similarity (0.667) at bs $=98 \%$. B. hasselti, a species of Osphronemidae, has grouped with other Osphronemidae species i.e. $T$. trichopterus (with gs $=0.583$ ) and $T$. pectoralis (with gs $=$ 0.533). However, differ from the non-precipitated, $T$. trichopterus and $T$. pectoralis are not sister taxa on this phylogenetic tree.

One phylogenetic tree was reconstructed based on the combination of non-precipitated and AS-precipitated datasets (Figure 4.C). These datasets produced some changes in phylogenetic tree, including bootstrap values and genetic similarity coefficient. In general, these datasets grouped fish population into two groups. The highest genetic similarity has been shown between $T$. trichopterus and T. pectoralis at 0.808 (bs $=99 \%$ ), and then between $H$. temminckii and A. testudineus at 0.591 (bs =98\%). This phylogenetic tree combined four Osphronemidae species in a group i.e $T$. trichopterus, $T$. pectoralis, $B$. hasselti and $O$. goramy (bs $=55 \%)$.

\section{Discussion}

Genetic diversity was manifested by differences in many characters, such as morphology; anatomy and proteins; enzymes; and DNA sequences of almost all organisms. It was required by populations to adapt the environmental changes (Frankham et al. 2004; Mursyidin et al. 2018). In our result, the AS-precipitated protein has shown the highest genetic polymorphism between fish population. Moreover, this result may be affected by ammonium sulfate treatment during extraction process of the muscle proteins. The results of SDS-PAGE analysis has been shown that the AS-precipitation process affected the reduction in the number of protein bands in the sample.

According to Crick (1963) and Nirenberg et al. (1963), protein or enzymes of the fish was able to use as genetic marker for diversity analysis and phylogenetic reconstruction between the population, because this marker is a product from genetic activity. Based on the study, the protein of Anabantoidei fish has show relatively high genetic polymorphism (greater than 90\%) on each dataset. The proteins of each species have been shown variation between the population of Anabantoidei fish in South 
Kalimantan, Indonesia. This variation resulted from the gene of the fish that is adapted to environmental changes. Some environmental changes have been affected by the protein expression on the fish, including geographical origin, fish aquaculture and water pollution on the freshwater ecosystem. According to Mabrur et al. (2018), the geographical origin of Channa striata has resulted some changes in protein profile of the fish, which was
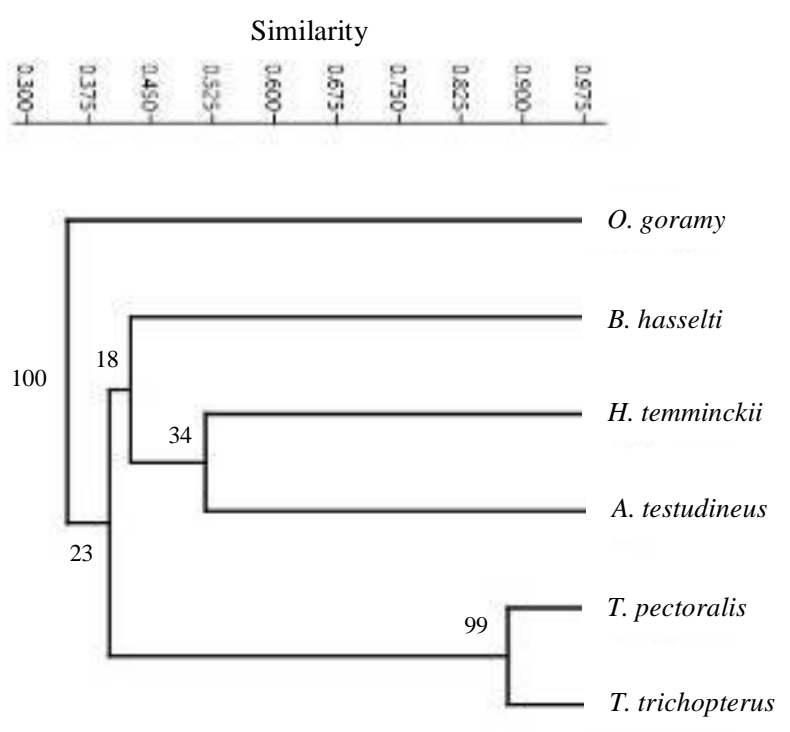

A

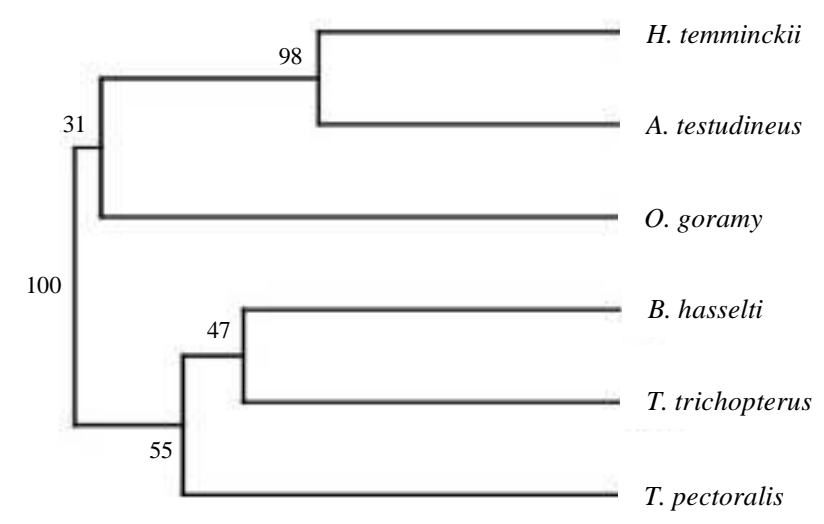

shown by the number of protein bands. The study of Mahboob et al. (2012), the wild and cultured L. rohita and $C$. mrigala has shown variation on the protein profiles. Water pollution, including heavy metal contamination, industrial wastewater, and pesticide used has resulted some changes in protein expression of the fish for adaptation due to the condition.

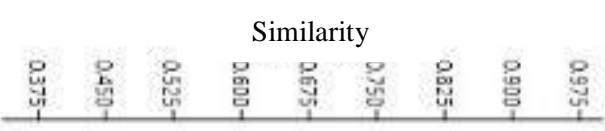

B
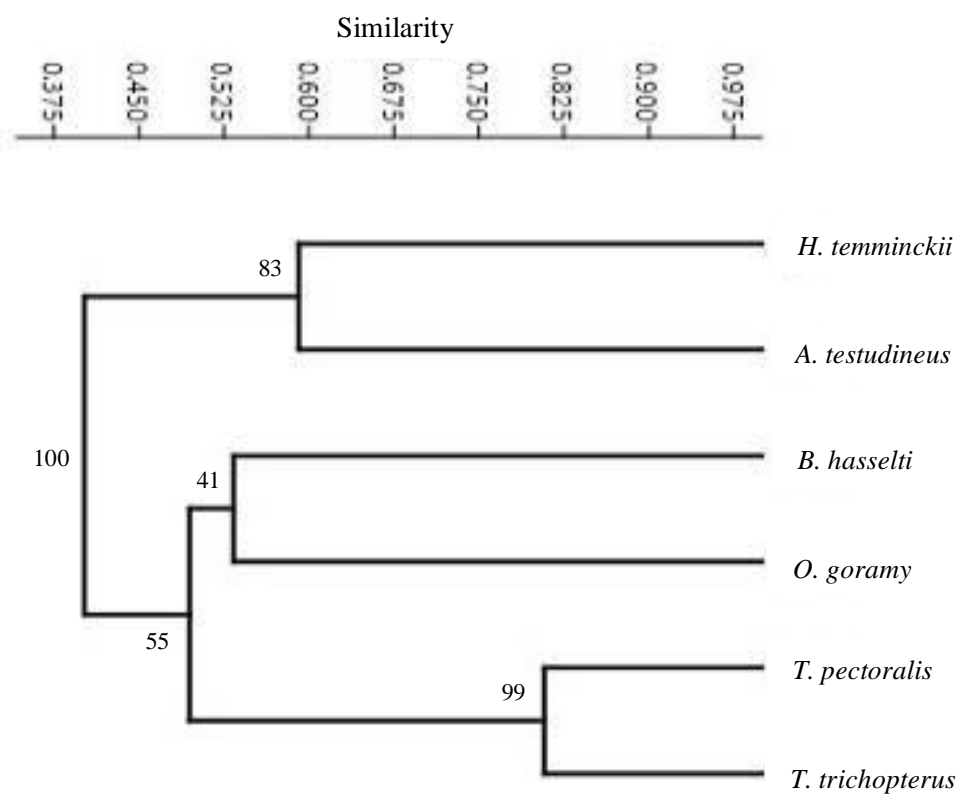

C

Figure 4. Diversity and phylogenetic tree of the Anabantoidei fish (Anabantiformes) based on protein profiles using SDS-PAGE analysis. A. Phylogenetic tree generated from non-precipitated protein profiles, B. AS-precipitated protein profiles, C. Combined dataset of non- and AS-precipitated protein profile. The numbers above branches indicate bootstrap values inferred from 1000 replicates 
Five protein bands of Anabantoidei fish was monomorphic: 47.91, 44.05. 34.48, 30.82 and $28.15 \mathrm{kDa}$. Other 54 protein bands was unique or polymorphism in the fish population. The unique and monomorphic protein of Anabantoidei fish would be useful as protein marker for breeding program and diversity analysis based on protein sequence. Moreover, this protein would be identified based on amino acid sequence using mass spectrometry (MS) to understand their character and function (Sabullah et al. 2015; Hidayaturrahmah et al. 2019).

Our results revealed the phylogenetic relationships of the Anabantoidei fish of the South Kalimantan, Indonesia based on non-precipitated and AS-precipitated protein datasets. Both reflected the differences in clustering when analyzed separately, the fish population was separated in to three groups for non-precipitated (Figure 4.A) and two groups for AS-precipitated protein (Figure 4.B). While these trees were generated by two different protein profiles, both have a low resolution, indicated by the average of bootstrap values of each tree. This condition was affected by the weakness of protein variation that used in this study due to the effect of extraction method. The extraction method used in this study resulted in some protein bands and eliminated some protein bands that are not soluble in the extraction buffer or can not precipitated by the ammonium sulfate. Thus based on these results, another phylogenetic tree was reconstructed by combined (non- and AS-precipitated protein) dataset to increase the phylogenetic tree resolution.

In this study, the combined dataset provided a better resolution of a phylogenetic tree (Figure 4.C), the highest average of bootstrap values when compared with protein profile data used separately. On this tree, Anabantoidei fish were separated into two different groups. The first group combined two fish species from different families i.e. $H$. temminckii (Helostomatidae) and A. testudineus (Anabantidae) as sister taxa. Ruber (2009) reported the same result of this study, where Helostomatidae and Anabantidae is a sister taxa based on the mitochondrial and nuclear gene i.e. recombination activating 1 (RAG1). However, Betancur-R et al. (2017) reported a different result, where Helostomatidae grouped with Osphronemidae as sister taxa based on the genome data. The second group combined four fish species from Osphronemidae i.e. $T$. trichopterus, $T$. pectoralis, B. hasselti, and $O$. goramy. On this tree, the closest relationship has been shown between $T$. trichopterus and $T$. pectoralis. Both grouped as Trichogaster genera that share the following morphological characteristics: body relatively laterally compressed and deep-bodied; short-based dorsal fin inserted at the middle of the body, far behind the pectoral fin base; pelvic fin a long filamentous ray and two to three small rays in the axil; lateral line interrupted or complete; and caudal fin emarginated to forked with rounded lobes (Low and Lim 2012).

According to Ruber (2009), Osphronemidae, Helostomatidae and Anabantidae were grouped in a monophyletic group (suborder Anabantoidei) that share labyrinth as morphological character. Moreover, suborder Channoidei also had labyrinth. Betancur-R et al. (2017) have been reported that the suborder Anabantoidei is a sister taxa with Channoidei. Both grouped into a new order i.e. Anabantiformes (Wiley and Johnson 2010) or Labyrinthici (Regan, 1909). In addition, suborder Nandoidei (Badidae, Nandidae, and Pristolepididae) was classified as order of Anabantiformes (Betancur-R et al. 2017). Differ from Anabantoidei and Channoidei, the suborder Nandoidei was homoplasy-free of their infrabranchial musculature (Datovo et al. 2014).

In conclusion, the protein profiles of Anabantoidei fish has high genetic polymorphism (greater than 90\%) with five monomorphic bands expressed on the $10 \%$ resolving polyacrylamide gels. The phylogenetic reconstruction also exhibited that the Anabantoidei fish has unique phylogenetic trees. The phylogenetic tree that constructed from combined dataset (non-precipitated and ASprecipitated protein profiles) provides better resolution of the phylogenetic relationship among Anabantoidei that reflected by the average of bootstrap values. On combined dataset, Anabantoidei fish were separated into two different groups. Furthermore, several studies are needed to study the genetic diversity and phylogenetic relationship among Anabantoidei fish based on mitochondrial or nuclear DNA for providing better phylogenetic tree resolution. Thus, this information would be useful for fish conservation and breeding programs in the future.

\section{ACKNOWLEDGEMENTS}

We are very grateful to the reviewer for their valuable comments and suggestion for improving this manuscript. This research was financially supported by PT. Indofood Sukses Makmur Tbk. through the Indofood Riset Nugraha program FY (2017-2018) under grant number of SKE.029/VIII/CC/2017 and Directorate General of Research and Development (Dirjen Risbang) through the (Penelitian Dosen Pemula) PDP research scheme FY 2017 under Grant Number of 01/E/KPT/2017, Ministry of Research, Technology \& Higher Education, Republic of Indonesia.

\section{REFERENCES}

Betancur-R R, Wiley EO, Arrataria G, Aceros A, Bailly N, Miya M, Lecointre G, Orti G. 2017. Phylogenetic classification of bony fishes. BMC Evol Biol 17 (162): 1-40.

Bone Q, Moore RH. 2008. Biology of Fishes. 3rd ed. Taylor and Francis Group, New York.

Bradford MM. 1976. A rapid and sensitive method for the quantitation of microgram quantities of protein utilizing the principle of protein-dye binding. Anal Biochem 72: 248-254.

Burgess RR. 2009. Protein Precipitation Techniques. In: Methods in Enzymology. Elsevier, Madison, USA.

Burnawi. 2009. Identification of fish species in Danau Talan fishery reserve, South Kalimantan. Buletin Teknik Litkayasa 7 (2): 43-46. [Indonesian]

Crick, RHC. 1963. On the genetic code. Science, New York.

Datovo A, de Pinna MCC, Johnson GD. 2014. The Infrabranchial Musculature and Its Bearing on the Phylogeny of Percomorph Fishes (Osteichthyes, Teleostei). PLoS ONE 9 (11): e112600. DOI: 10.1371/journal.pone.0112600. 
Dekic R, Friscic J, Ivanc A, Kukavica B. 2016. Characterization of proteins from Popovo minnow (Delminichthys Ghetaldi Steindachner, 1882) muscle. Turkish J Fisher Aqua Sci 16: 637-642.

Dumetz AC, O'Brien AMS, Kaler EW, Lenhoff AM. 2007. Patterns of protein-protein interactions in salt solutions and implications for protein crystallization. Protein Sci 16: 1867-1877.

Ebied ABM, Aly FM, Abu-AlMaaty AH, Allam M. 2014. Assessment of Genetic variation and Changes in Protein Subunits induced by Petroleum Oil in the Three Species of Red Sea Fishes using SDS PAGE and ISSRs markers. IOSR-J Pharm Biol Sci 9 (6): 16-22.

Elghobashy HA, Rahman AA, Ibrahem LH, Rashed MA. 2005. Phylogenetic relationships for some Tilapia species using electrophoresis. Egypt J Exp Biol 1: 57-63.

Fenselstein J. 1985. Confidence-limits on Phylogenies - An Approach using the bootstrap. Evolution 39: 783-791.

Fishbase. 2019. List of Freshwater Fishes Reported from Indonesia http://www.fishbase.org

Frankham R, Ballou JD, Briscoe, DA. 2004. A Primer of Conservation Genetics. Volume 39. Cambridge University Press, New York, USA.

Gam LH, Leow CW, Baie S. 2006. Proteomic analysis of snakehead fish (Channa striata) muscle tissue. Malaysian J Biochem Mol Biol 14: 25-32.

Hammer $\varnothing$, Harper DAT, Ryan PD. 2001. PAST: Paleontological statistic software package for education and data analysis. Paleontologia Electronica. 4 (1): 1-9.

Haniffa MA, Sheela PJ, Milton JM., Kavitha K. 2017. Protein profiling for phylogenetic relationship in snakehead species. Iranian J Fisher Sci 16 (4): 1178-1186.

Haryono. 2012. Peat Swampland Ichthyofauna in the rainy season in Central Kalimantan. Jurnal Iktiologi Indonesia. 12 (1): 83-91 [Indonesian]

Hidayati D, Abdulgani N, Setiyawan H, Trisnawati I, Ashuri NM, Nailis N. 2016. Analysis of protein profiles in diabetic rat blood plasma induced by alloxan. AIP Conf Proc 1854: 020016.1-020016.6.

Hidayaturrahmah, Mabrur, Santoso HB, Sasmita R, Rahmy USA Badruzsaufari. 2019. Protein profiles of Giant Mudskipper and its potential use as biomarker candidate for heavy metal contamination in Barito Estuary, Indonesia. Biodiversitas 20 (3): 745-753.

Karp A, Kresovich S, Bhat KV, Ayad WG, Hodgkin T. 1997. Molecular Tool in Plant Genetic Resources Conservation: A Guide To The Technologies. IPGRI Technology Bulletin. No. 2. FAO, Rome.

Kottelat M, Whitten T. 1996. Freshwater biodiversity in Asia with special reference to fish. World Bank Technical Paper No. 343, World Bank, New York.

Laemmli UK. 1970. Cleavage of structural proteins during the assembly of the head of bacteriophage T4. Nature. 227: 680-685.

Low BW, Lim KKP. 2012. Gouramies of the genus Trichopodus in Singapore (Actinopterygii: Perciformes: Osphronemidae). Nat Sing 5: 83-93.

Mabrur, Rahmy USA, Sasmita R, Badruzsaufari. 2018. Protein Profiles of Haruan Fish (Channa striata) from South Kalimantan. In: Soendjoto MA, Dharmono, Riefani MK, Ansari ML, Septiyan RA, Syahdi N. (eds.) The Potency, Opportunity, and Challenges in Wetland Management; Proceeding of National Seminar on Wetland Environment 3 (1): 39-45. Universitas Lambung Mangkurat Banjarmasin, 11 November 2017. [Indonesian]

Mahboob S, Farooq M, Mahmood S, Nasir N, Sultana S, Chaudhry AS, Al-Akel AS, Al-Balawi HFA, Al-Minsed F, Al-Ghanim KA. 2012. Phylogenetic relationship of cultured and wild Labeo rohita and Cirrhinus mrigala based on muscle protein profile in different weight groups: a new tool in phylogenetic analysis. Intl J Food Properties 15 (5): 949-960

Maidie A, Sumoharjo, Asra SW, Ramadhan M, Hidayanto DN. 2015 Development of betok fish tiller (Anabas testudineus) for household industry. Media Akuakultur 10 (1): 31-37.

Mursyidin DH, Purnomo P, Sumardi I, Daryono BS. 2018. Molecular diversity of tidal swamp rice (Oryza sativa L.) in South Kalimantan, Indonesia. Diversity 10 (22): 1-10.

Nei M, Li WM. 1979. Mathematical model for studying genetic variation in terms of restriction endonuclease. Proc Natl Acad Sci USA 76: 5269-5273.
Nelson JS. 2016. Fishes of The World. 5th ed. John Wiley \& Sons, Inc., New Jersey, USA

Nirenberg MW, Mathaei JH, Jones OW, Martin RG, Burondes SH. 1963. Approximation of genetic code via, cell-free protein synthesis detected by template RNA. Federation Proceedings 22: 55-61.

Porto JIR, Gomes JAA, Farias IP, Feldber E. 2015. Using molecular biology techniques to characterize the diversity of Amazonian ornamental fishes. In: Chao NL, Petri P, Prang G, Soneschien L, Tlusty M (eds). Conservation and Management of Ornamental fish Resources of the Rio Negro Basin, Amazonia, Brazil (Project Piaba). Universidade do Amazonas Press, Manau.

Prasetyo D, Asyari. 2003. Inventory of Fish species and Limnological characteristics of Barito River. Prosiding Pusat Riset Perikanan Tangkap, Jakarta: 23-31. [Indonesian]

Prasetyo D. 2006a. Fishing Activities in the Sambujur River Fisheries in the Central Barito River Basin, South Kalimantan. J Fish Sci 8 (2): 239-246. [Indonesian]

Prasetyo D. 2006b. Fishing activities in the Danau Panggang fishery reservoir, District of Hulu Sungai Utara, South Kalimantan. Balai Perikanan dan Peraian Umum, Palembang. [Indonesian]

Quyen VDH, Phuong TTL, Oanh TT, Thuoc TL, Binh DT. 2015. Phylogenetic Relationship of Freshwater Fish in Vietnamese Mekong. International Conference on Biological, Environment and Food Engineering (BEFE), Singapore

Rath A, Cunningham F, Deber CM. 2013. Acrylamide concentration determines the direction magnitude of helical membrane protein gel shifts. Proc Nat Acad Sci USA 110 (39): 15668-15673.

Regan CT. 1909. The classification of teleostean fishes. Ann Mag Nat Hist 8: 75-86.

Roy S, Kumar V. 2014. A practical approach on SDS PAGE for separation of protein. Intl J Sci Res 3 (8): 955-960.

Ruber L. 2009. Labyrinth Fishes (Anabantoidei). In: Hodges SB, Kumar S (eds.). The Timetree of Life. Oxford University Press, London.

Sabullah MK, Ahmad SA, Shukor MY, Gansau AJ, Syed MA, Sulaiman MR, Shamaan NA. 2015. Heavy metal biomarker: Fish behavior, cellular alteration, enzymatic reaction and proteomics approaches. Intl Food Res J. 22 (2): 435-454

Sasmita R, Susilawati IO, Rahmy USA, Mabrur. 2018. Protein profile from Catfish (Pangasius hypophthalmus) and Baung Fish (Hemibagrus nemurus) Muscle from South Kalimantan. Appl Sci Technol 2 (1): 230-234.

Saxena A, Soranganba N. 2014. Proteins diversity in various tissue of the body of carps. Biol Chem Res 1: 108-122.

Subharanjani S, Prema P, Immanuel G. 2015. Supplementation of Bacillus cereus as probiotic in fish fed of Trichogaster trichopterus (Blue Gourami) and calculating its growth and survival. Intl J Curr Microbiol App Sci 4 (12): 744-751.

Thada V, Jaglan DV. 2013 Comparison of Jaccard, Dice, Cosine Similarity Coefficient to find best fitness value for web retrieved documents using genetic algorithm. Intl J Innov Eng Technol 2 (4): 202-205.

Velamala GR, Babu KR, Naranji MK. 2017. Genetic information of Snappers (Family: Lutjanidae) from Indian Waters Using SDS-PAGE Technique. Gen Aqua 1: 49-55

Wiley EO, Johnson GD. 2010.A teleost classification based on monophyletic groups. In: Nelson JS, Schultze HP, Wilson MVH (eds.). Origin and Phylogenetic Interrelationships of Teleosts. Verlag Dr. Friedrich Pfeil, Munchen.

Wingfield PT. 2001. Protein Precipitation Using Ammonium Sulfate. Curr Protoc Protein Sci HHS Public Acces: 1-10.

Yunita R. 2012. The characteristic of Danau Bangkau and its fish diversity in District of Hulu Sungai Selatan, South Kalimantan. Ecotrophic 5 (1): 34-41. [Indonesian]

Zhang JF. 2012. Protein-protein Interaction in Salt Solutions. In: Cai W (eds.). Protein-Protein interaction Computational and Experimental Tools. Intech, Rijeka, Croatia.

Zhuo H, Guo XY. 2015. Soil heavy metal pollution evaluation around mine area with traditional and ecological assessment methods. J Geosci Environ Protect 3: 28-33. 